\title{
Wolf in a sheep's clothes: juvenile coney (Cephalopholis fulva) as an aggressive mimic of the brown chromis (Chromis multilineata)
}

\author{
Ivan Sazima*, João Paulo Krajewski*, \\ Roberta Martini Bonaldo* and Cristina Sazima*,**
}

We found yellowish juvenile coneys (Cephalopholis fulva) at Fernando de Noronha Archipelago, off Northeast Brazil, joining schools of similarly sized and coloured brown chromis (Chromis multilineata) when these latter closely approach the rocky reefs. Mingled within the mid-water hovering group of the plankton-feeding chromis, the piscivorous coney is able to approach unaware prey - an instance of aggressive mimicry. Three out of four coney individuals hunting under such disguise were successful in their attempts to prey on the otherwise wary rock-dwelling blenny (Malacoctenus species). This is the first instance of an epinepheline grouper mimicking a schooling and plankton-eating damselfish model in the West Atlantic.

Encontramos piraúnas (Cephalopholis fulva) juvenis amareladas, no arquipélago de Fernando de Noronha, associando-se a cardumes de mulatas (Chromis multilineata) de tamanho e cor semelhantes, quando estas se aproximam de recifes rochosos. Misturadas ao grupo destes peixes planctófagos, a meia-água, as piraúnas conseguem se aproximar de presas desatentas - um exemplo de mimetismo agressivo. Três de quatro indivíduos de piraúna, caçando sob este tipo de disfarce, foram bem sucedidos nas suas tentativas de apresar o amborê Malacoctenus species, uma presa habitualmente arisca. Este é o primeiro registro, no Atlântico Ocidental, de uma espécie de Epinephelinae mimetizando uma espécie de Pomacentridae que encarduma e se alimenta de plâncton.

Keywords: Mimicry, hunting tactic, epinepheline grouper, plankton-feeding damselfish

In the most classical mimicry examples among fishes, an aggressive mimic resembles a beneficial or otherwise harmless model in which guise the mimic approaches and preys on its unaware victims (Wickler, 1968; reviews in Sazima, 2002; Randall, in press). Examples of aggressive mimicry in marine fishes include species whose feeding habits vary from preying on whole smaller fishes and crustaceans to taking scales from larger fishes (e.g., Randall \& Randall, 1960; Ormond, 1980; Sazima, 2002). In most instances the mimic fish resembles, and associates with, planktivorous, micro-carnivorous, or herbivorous fishes (Ormond, 1980; Randall \& Kuiter, 1989; Sazima, 2002; Randall, in press).
In a recent review of aggressive mimicry in fishes, Sazima (2002) described two examples of this disguise type in juvenile groupers (Serranidae) in the southwest Atlantic, and predicted that additional instances will be found among epinepheline groupers. Here we describe aggressive mimicry for juvenile coneys, Cephalopholis fulva (Serranidae), mimicking juvenile brown chromis, Chromis multilineata (Pomacentridae). The coney joins schools of chromis when the latter closely approach the rocky reefs on which it dwells. While mingled with these planktivores, the coney strikes at smaller fish on the reef. This is the first example of an aggressive mimic in the southwest Atlantic whose model is a school-

\footnotetext{
*Departamento de Zoologia e Museu de História Natural, Caixa Postal 6109, Universidade Estadual de Campinas, 13083-970 Campinas, São Paulo, Brazil. e-mail: isazima@unicamp.br

**Departamento de Zoologia, Caixa Postal 199, Universidade Estadual Paulista, 13506-900 Rio Claro, São Paulo, Brazil.
} 


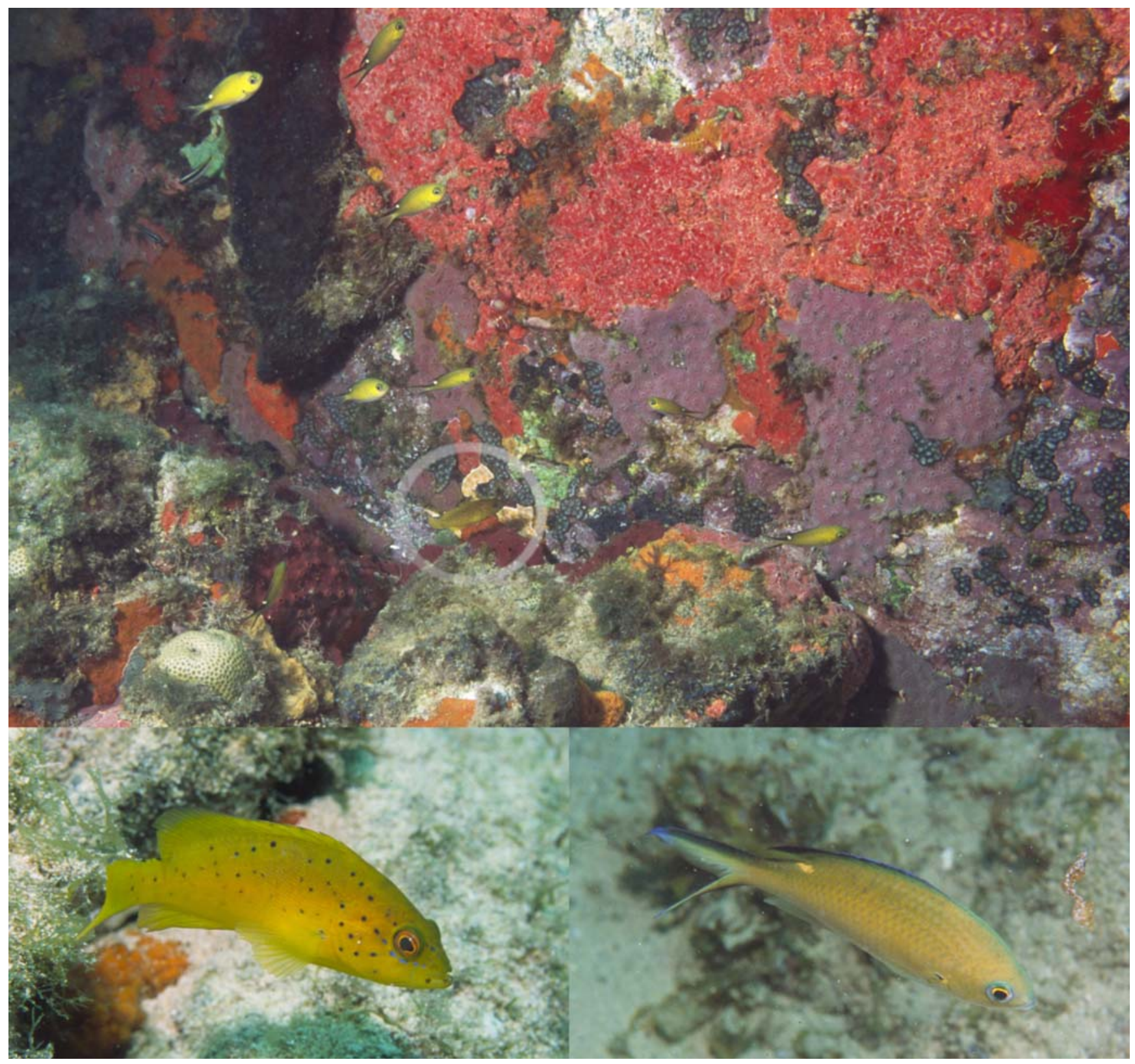

Fig. 1. A juvenile coney (Cephalopholis fulva) (circle) joins a school of brown chromis (Chromis multilineata) that is nearing a rocky reef at Fernando de Noronha Archipelago, off Northeast Brazil (above). A juvenile coney (left) and a similarly sized brown chromis (right) photographed alone.

ing planktivorous fish (reviews in Sazima, 2002; Randall, in press), and supports Sazima's (2002) prediction on juvenile epinepheline groupers.

Fieldwork was conducted in October 2004 at the Praia do Sancho, Fernando de Noronha Archipelago (035ㅇ's, $32^{\circ} 25^{\prime} \mathrm{W}$ ), off Northeast Brazil (see Maida \& Ferreira, 1997; Carleton \& Olson, 1999 for maps and description). The reef is composed of large rocky boulders covered mostly with sponges and algae, and its outer edges support an assemblage of planktivorous fishes including Chromis multilineata (Fig. 1). Behavioural events involving the mimic, its model, as well as potential and actual prey were recorded while scuba diving in two non-consecutive days. Focal individual and all occurrences samples (Altmann, 1974) were used in five observation sessions of 15-50 min, totalling $135 \mathrm{~min}$. Records were made on a plastic slate and photographed. Total lengths of fishes were estimated visually by comparison with objects of known size (see Sazima et al., 1999).

The observed juvenile coneys were yellowish with scattered brown spots and had orange eyes with a few blue tinges around, bearing an overall resemblance to the brown chromis (Fig. 1). Two to three pale yellow spots on the coney's dorsum and upper part of caudal peduncle add to the resemblance (Fig. 2). A total of four juvenile coneys ranging about 
4-7 cm total length (TL) were observed in crevices and holes of the rocky reef. They occasionally left their shelters for short forays over the reef, moving close to the substrate while doing so. No predation attempt was recorded during 16 of these forays (35 min total time), but in three occasions a potential prey fish, the scaled blenny Malacoctenus sp., was seen retreating into its shelter upon a coney's approach.

When a school of the brown chromis approached a coney's shelter $(\mathrm{n}=11)$, the coney moved towards the schooling fish (Fig. 1) and mingled with them in midwater. While within the school the coney swam with its median fins folded down, thus behaviourally adding to its size and overall colour resemblance with the chromis model.

As the school moved over the reef the coney watched the substrate, probably searching for its potential unaware prey. While mingled with the brown chromis, the coney occasionally darted at potential prey on the reef. Eight attacks to preys were recorded during the observation period (about 3.5 strikes.hour $^{-1}$ ), three of them successful. Thus, predation success was about $37 \%$. In all preying attempts the target fish was the blenny Malacoctenus sp., ranging about 2-4 cm TL. After a successful strike, the coney immediately sheltered to engulf its prey. In addition to the above-mentioned successful attacks, a coney was recorded sheltered in a crevice swallowing a blenny almost its own size.

In the same reef area we recorded several coneys 10-25 $\mathrm{cm}$ TL foraging over the substrate, lying in wait in crevices, or following zoobenthivorous fishes that disturb the substrate during their feeding activity (Strand, 1988; DeLoach, 1999). These larger coneys had variable colours including combinations of blackish brown and whitish, reddish, or marbled brown (see DeLoach, 1999; Humann, 2002, for some of these colour forms), but no individual had the yellowish pattern we recorded for the small, juvenile mimics.

No coney larger than $10 \mathrm{~cm}$ TL was ever recorded moving towards, or schooling with, the brown chromis. Coneys this size rarely venture into midwater, foraging close to the reef instead (DeLoach, 1999; our pers. obs.). Since the brown chromis attains $20 \mathrm{~cm}$ TL (Carvalho-Filho, 1999), we have no plausible explanation other than intrinsic colour and behaviour changes for coneys larger than $10 \mathrm{~cm}$ TL not also joining the schools of the damselfish. In this respect, the coney differs from what is known for other aggressive mimics that disrupt this hunting tactic and even change their colour pattern when they outgrow the model (reviews in Sazima, 2002; Randall, in press).

Yellowish juvenile coneys may be regarded as a good example of aggressive mimicry (reviews in Sazima, 2002; Randall, in press) similar to that of juvenile tiger grouper, Mycteroperca tigris, whose model is the schooling and plankton-picking bluehead wrasse, Thalassoma bifasciatum (Labridae) in the Caribbean (Snyder, 1999; DeLoach, 1999). As in the case of juvenile coney, the tiger grouper was recorded successfully preying on smaller fishes while amidst its model's schools (Snyder, 1999). Both groupers fit the facultative mimicry relationship as defined by Russell et al. (1976).

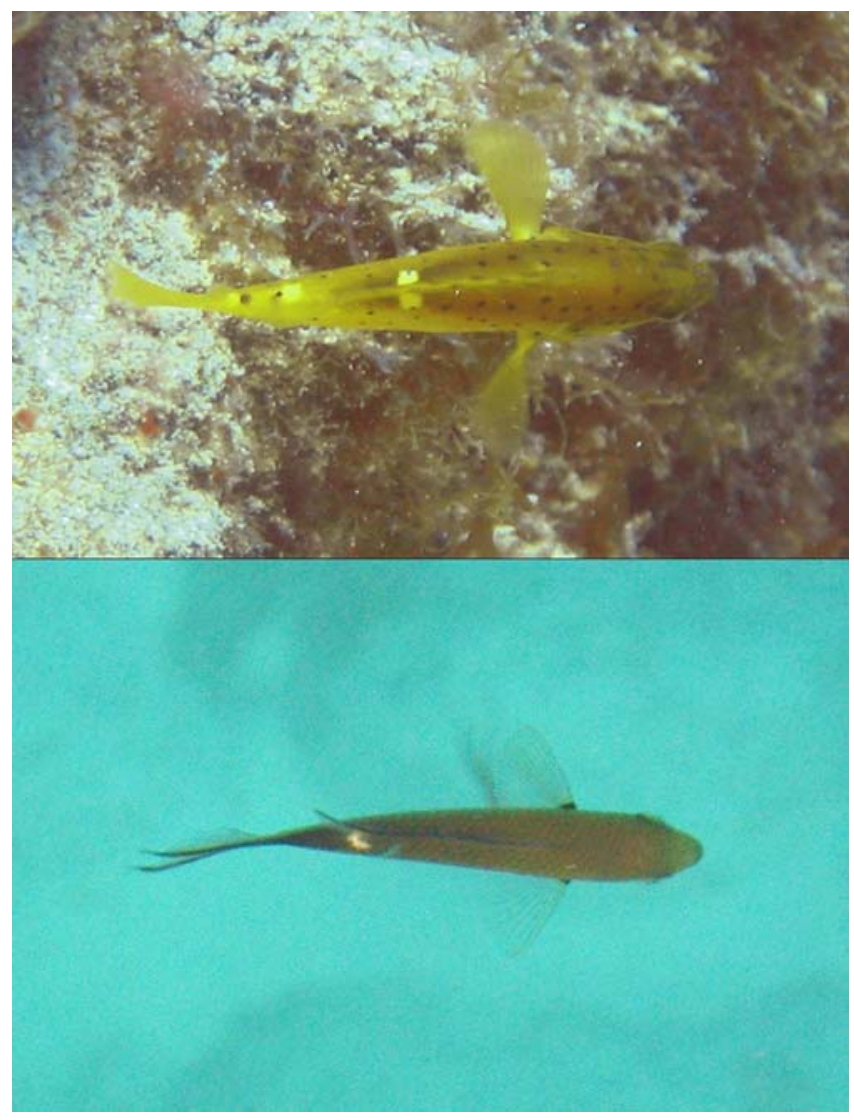

Fig. 2. Juvenile coney (above) and brown chromis (below) in dorsal view showing pale yellow spots on dorsum.

The habits of the mimics are relatively unspecialised, the resemblance to their models is superficial, the mimics aggregate with the model, the relationship is opportunistic, only one mimicry element (aggressive) is involved, and the groupers mimic their models only as juveniles (reviews in Sazima 2002; Randall, in press).

Mimicking coneys illustrate the category 1 of the three groupings proposed by Sazima (2002) for aggressive mimics. In this category several species mimic either gregarious plankton-eating pomacentrids or labrids, and prey on fishes smaller than themselves. Additional examples are illustrated by Russell et al. (1976), Snyder (1999), Sazima (2002) and Randall (in press). Putative models for aggressive mimicry involving epinepheline groupers include wrasses (Labridae), angelfishes (Pomacanthidae), damselfishes (Pomacentridae), and puffers (Tetraodontidae) (reviews in Sazima, 2002, Randall, in press). In the West Atlantic only wrasses are recorded as models for epinepheline groupers (Snyder, 1999; Sazima, 2002), ours being the first record for this region of a damselfish as a model.

Several juvenile epinepheline species have an appearance distinct from those of adults, and some of these species are recorded as aggressive mimics (reviews in Sazima, 2002; Randall, in press). Thus, additional instances of aggressive mimicry are to be expected when field studies focus on the behaviour of juvenile groupers. 


\section{Acknowledgements}

We thank J.M. Silva Jr. for logistics and his always helping hand; the IBAMA (through M.A. Silva) for issuing study permits at the Fernando de Noronha National Marine Park; the Águas Claras, Atlantis, and Noronha Divers diving centres for allowing free use of their facilities; the CAPES, CNPq and FAPESP for essential financial support. CS and IS are recipients of scholarships from the $\mathrm{CNPq}-\mathrm{Brazil}$. Two anonymous referees improved the paper.

\section{Literature Cited}

Altmann, J. 1974. Observational study of behavior: sampling methods. Behavior, 49:227-267.

Carleton, M. D. \& S. L. Olson. 1999. Amerigo Vespucci and the rat of Fernando de Noronha: a new genus and species of Rodentia (Muridae: Sigmodontinae) from a volcanic island off Brazil's continental shelf. American Museum Novitates, 3256:1-59.

Carvalho-Filho, A. 1999. Peixes: costa brasileira. Melro, São Paulo, 304p.

DeLoach, N. 1999. Reef fish behavior: Florida, Caribbean, Bahamas. Jacksonville, New World Publications, 359p.

Humann, P. 2002. Reef fish identification: Florida, Caribbean, Bahamas. New World Publications, Jacksonville, 481 p.

Maida, M. \& B. P. Ferreira. 1997. Coral reefs of Brazil: an overview. Proceedings of the $8^{\text {th }}$ International Coral Reef Symposium, 1:263-274.

Ormond, R. F. G. 1980. Aggressive mimicry and other interspecific feeding associations among Red Sea predators. Journal of Zoology, London, 191:247-262.
Randall, J. E. (in press). A review of mimicry in marine fishes. Zoological Studies.

Randall, J. E. \& R. H. Kuiter. 1989. The juvenile Indo-Pacific grouper Anyperodon leucogrammicus, a mimic of the wrasse Halichoeres purpurascens and allied species, with a review of the recent literature on mimicry in fishes. Revue Française d'Aquariologie et Herpetologie, 16:51-56.

Randall, J. E. \& H. A. Randall. 1960. Examples of mimicry and protective resemblance in tropical marine fishes. Bulletin of Marine Science, 1:444-480.

Russell, B. C., G. R. Allen \& H. R. Lubbock. 1976. New cases of mimicry in marine fishes. Journal of Zoology, London, 180:407-423.

Sazima, I. 2002. Juvenile snooks (Centropomidae) as mimics of mojarras (Gerreidae), with a review of aggressive mimicry in fishes. Environmental Biology of Fishes, 65:37-45.

Sazima, I., R. L. Moura \& C. Sazima. 1999. Cleaning activity of juvenile angelfish, Pomacanthus paru, on the reefs of the Abrolhos Archipelago, western South Atlantic. Environmental Biology of Fishes, 56:399-407.

Snyder, D. B. 1999. Mimicry of initial-phase bluehead wrasse, Thalassoma bifasciatum (Labridae) by juvenile tiger grouper, Mycteroperca tigris (Serranidae). Revue Française d'Aquariologie et Herpetologie, 26:17-20.

Strand, S. 1988. Following behavior: interspecific foraging association among Gulf of California reef fishes. Copeia, 1988:351-357.

Wickler, W. 1968. Mimicry in plants and animals. New York, McGraw Hill, 255p.

Received May 2005

Accepted June 2005 